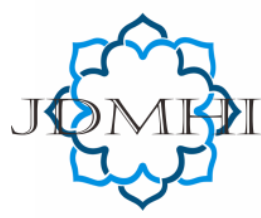

email: jdmhi@walisongo.ac.id

Journal of Digital Marketing and Halal Industry

ISSN: 2716-4810 (print) ISSN: 2716-4802 (online)

\title{
The Role of Mediating Islamic Personality and Value Satisfaction on the Effect of Relationship Marketing on Customer Loyalty
}

\section{Bambang Widarno}

Universitas Slamet Riyadi Surakarta, Indonesia

\section{A R T I C LE I N F O}

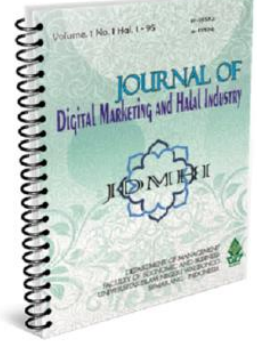

Article history:

Received 21 August 2020

Accepted 15 October 2020

Published 30 October 2020

Keywords:

Relationship marketing, Islamic personality, Value satisfaction, Consumer loyalty

\section{A B S T R A C T}

The study of consumer loyalty to a product is an essential topic for academics and practice. There is not much empirical research on the effect of marketing on allegiance, based on the literature review; it has produced propositions that determine consumer loyalty in a product influenced by marketing effectiveness. This study uses a qualitative approach to using literature studies. Based on a literature review, it produces propositions that determine consumer loyalty in a product influenced by marketing effectiveness. Besides, there is a mediating effect of Islamic personality and consumer perceived value satisfaction. This study also links value satisfaction and customer value loyalty. Islamic personality is a mediating variable. This study also discusses the combination of perceived value and consumer satisfaction into value satisfaction.

@2020 Journal of Digital Marketing and Halal Industry

\section{Introduction}

The marketing mix management paradigm has dominated marketing thinking for more than 65 years. The marketing mix paradigm is starting to lose its position (Thommen et al., 2020). New approaches have emerged in marketing research. Business globalization and growing recognition of the importance of customer retention and the market economy and customer relationship economy, among other trends, are amplifying changes in mainstream marketing. In an era of advanced information technology like now, direct marketing has returned to a relationship orientation. Most academics argue that with the evolution of relationship marketing, the marketing exchange paradigm that has prevailed hitherto will not be sufficient to

\footnotetext{
* Corresponding author. email: bambangwidarno@unsri.ac.id DOI: http://dx.doi.org/10.21580/jdmhi.2020.2.2.6156
} 
explain the marketing phenomenon developed from the collaborative involvement of customers in the production process. An alternative marketing paradigm needs to be developed that is more process than resultsoriented. It emphasizes value creation rather than value distribution (J. N. Sheth \& Parvatiyar, 2015). Advances in information technology have made relationship marketing programs more affordable, feasible, and robust (J. Sheth et al., 2014).

The intense competition that has developed a better understanding of what drives consumer loyalty towards a product has become an essential issue for academics and practitioners (Yeh et al., 2016). The emergence of relationship marketing signifies a paradigm shift in marketing theory and practice from traditional transactional approaches. This new relationship orientation seems particularly appropriate for service firms and business-tobusiness, gaining significant benefits by adopting a relational process (Iglesias et al., 2011). Marketing's role is to facilitate decisions seeking rational utility in competitive markets (O'Malley, 2014).

Companies can increase market share in three ways: attracting more new customers, doing more business with existing customers, and reducing customer losses. By directing marketing resources to live, customers, and direct relationship marketing take care of these two opportunities (J. Sheth et al., 2014). Avoiding a focus on marketing as management, recent developments suggest that co-creation offers exciting possibilities as the basis for a new lexicon in marketing (O'Malley, 2014). Actors create shared value through 'integrating, exchanging, and creating shared resources through a network of relationships' (Möller, 2013). In contrast to the suggestion that marketing considers only customer relationships (Parvatiyar \& Sheth, 2000), co-creation demands a more holistic perspective. What is surprising is the research findings (Alrubaiee \& Al-Nazer, 2010) that commitment tends not to impact customer loyalty in Jordanian banking services. This inconsistent but interesting finding is investigated further. The study we conducted outside of the eight types of guiding factors for researchers explored the various forms that affect relationship marketing success, which are described including resources, competence, internal marketing, information technology, market offer, historical factors, public policy, and relations. (Hunt et al., 2006), namely, by trying to include Islamic / religious personality factors and satisfaction scores. As stated (Iglesias et al., 2011) that to successfully implement a marketing relationship orientation, it is necessary to develop a corporate culture that will support it, including personal personality and satisfaction at the value believed.

Relationship marketing theory and practice are further developed. We hope this review will provide useful guidance for those involved. There is still a lack of empirical research on relationship marketing's effect on loyalty, based on the literature review. It produces propositions that determine consumer loyalty in a product influenced by the effectiveness of relationship marketing. This study also discusses the mediating effects of religious personality and the value satisfaction felt by consumers. This concept is the first that connects value satisfaction and customer value loyalty. After reviewing the literature, finally, six propositions are 
proposed to be followed up into empirical research.

\section{Literature Review}

\section{Relationship marketing}

The impetus for the development of relationship marketing comes from the maturing of marketing services, emphasizing quality, increased recognition of potential benefits for the company and customers, and advances in technology. Rapid interest and active research are expanding this relationship marketing concept by incorporating newer and more sophisticated viewpoints. Newly emerging perspectives are being explored, including targeting profitable customers, using the most powerful possible strategy for customer engagement, marketing to employees and other stakeholders, and building trust as a marketing tool (J. Sheth et al., 2014).

The goal of relationship marketing theory is to provide a systematic structure that, at least, explains the relationship marketing phenomenon. (Hunt et al., 2006) suggest that the superiority of relationship marketing is due to the increase in service, technology, and information-oriented companies and to increasing strategic network competition. Strategic network competition, which involves independently owned and managed companies agreeing to be partners in the network, emphasizes the importance of cooperation between companies to compete successfully with other networks. To be successful (both individually and as a network), companies in strategic networks must become proficient at relationship marketing.

According to (Styles \& Ambler, 2003) the transactional approach and the relational approach not only coexist but operate to strengthen each other. Companies operating in highly relational societies, such as China, also exhibit transactional behavior, implying that the two approaches are compatible. Dramatic changes in the marketing landscape, including the decline of large bureaucratic organizations and an increase in strategic alliances and business partnerships, serve to reignite interest in relationships as an appropriate lens through which business activity can be understood and managed. The ideas that emerge unite into a body of knowledge known as Relationship marketing (O'Malley, 2014).

\section{Islamic Personality}

Due to different cultural orientations or values, there is an urgent need to develop specific Islamic personality models that are universal and explain people's behavior among cultural differences (Khir et al., 2016). According to the Prophet Muhammad's farewell sermon, "... white people are not superior to black people, and black people are not superior to whites, except by piety and good deeds". Nik Ahmad Hisham \& Tekke, (2015) argue that Tauhid and Nubuwwa (prophethood) cannot be separated based on Islamic testimony, following each other in relative terms. In this sense, the construction of "Nubuwwa," followed by "Tauhid", introduced by Nursi, became a doctrine that overshadows belief in Islamic personality measurement.

The literature review leads to discovering Islamic personality constructs (Nik Ahmad Hisham \& Tekke, 2015), namely Tauhid, Nubuwwa, self-striving, and self-respect, which act as indicators for the personality being measured. For organizations that require business effectiveness, it is vital to recognize 
and confirm the identity of the salesman who predicted the elite in offering goods. The personality characteristics of sales representatives have been characterized by Churchill et al. (2002) as mental qualities that increase men's capacity to perform. Following this view, many studies have been directed concerning looking at the effects of identity characteristics on Sales Performance.

The personality of a Muslim, according to Saeed \& Siddiqui, (2020), is Taqwa, forgiveness, and truth. Taqwa intends to discipline Allah's rules by doing what $\mathrm{He}$ commands and keeping a distance from what He forbids (Al-Sharawi, 2004). Ali (1997) explains that "Taqwa is the fear of going against the will of Allah; it is similar to worship Allah. , because we are afraid to disturb those we value; it brings the right results, and the people who do it are individuals who may be doing the right thing ". Anyone who accepts and watches over Allah's principles in his safety as in his open life is a man with Taqwa (Al-Atrash, 2002). Taqwa includes every principal deed, and it is Allah's advice to all Prophets and humans when all is said to be done (Al-Qurtobi, 2000). Al-Sharawi (2004) shows that verses 2: 3-4 and 2: 177 clarify the qualities of individuals who have Taqwa. The Qur'an characterizes Taqwa by describing the qualities of Muttaqqeen as in the accompanying verses (2: 1-4), (2: 177), and (3: 133-136) (Al-Atrash, 2002).

The Islamic Personality Model, according to Othman et al. (2014), Khir et al. (2016) namely, 'al-rushd', which includes diligence, frugality, moderation, and balance. The 'veil' reflects a person taking care of his right name, not committing sins, being patient and tawakkal, and being sincere. Deliberation is consultation. Refrain from speaking that is not productive and shows simplicity. Teamwork, consultative, participative, egalitarian. Spirituality, which includes worship, trust, and knowledge. Muslim characteristics like this can be used as a guide in perfecting the Islamic Personality Model.

Initially, these Muslim characteristics can be used further to refine the dimensions of the Islamic Personality Model. According to (N. Othman, 2015) Islamic personality psychology stands as an essential feature in understanding Islamic psychology. Humans, who are physical and metaphysical, are undoubtedly complex creatures. It is material because it involves the study of man and his personality as well as metaphysics. After all, he studies a person's invisible things, such as his heart, mind, spirit, and soul.

\section{Value satisfaction}

Value satisfaction is a combination of perceived value and consumer satisfaction. The study of technological marketing has recognized that technology products have various tangible and intangible attributes by grouping all these attributes into performance, appearance, and communication. Lee, Ha, and Widdows (2011) suggest that technology products can provide value to consumers through these three types of attributes. Consumers get functional value if a technology product's performance attributes are useful, easy to use, and innovative. A technology product with an attractive appearance, unusual materials, and design positively evokes consumer feelings and offers consumers emotional value.

Besides, technology products can become symbols themselves and carry symbolic 
meaning, enabling consumers to communicate their lifestyle and beliefs to others, thereby obtaining social value. Exploring product attributes (e.g., cell phones), Horváth and Sajtos (2002) identified utility/usability, experience/enjoyment of use, and power / communicative expression as three primary product-related consumer responses. Zeithaml (1988) explores the notion of consumer value found to be evolutionary and can be derived from utility theory in economics, which assumes consumer purchasing decisions are based on product evaluation (Nadhifah \& Adinugraha, 2020). According to the utility maximization principle, a product/brand with superior attributes to other alternatives is chosen because product performance is expected to meet consumer needs better. Satisfying requirements is seen as consumer value. An understanding of value creation in the context of customer purchases and consumption is required (Grönroos, 2008).

The customer is not a passive object of the marketing action but a resource actively participating in the process. Considering the different approaches to the concept of shared value creation (Saarijärvi, Kannan, \& Kuusela, 2013), from the perspective of dominant logic (Vargo \& Lusch, 2004), service is the fundamental unit of exchange. Customer skills and knowledge influence the value creation process. Thus, value is a joint function of suppliers' and customers' actions and is always the result of collective creation (Vargo \& Lusch, 2008). "The value creation perspective is broadened as companies and customers find new and innovative ways to support each other's value creation processes. These mechanisms shift focus outside of traditional exchanges. Value co-creation as a business concept seeks to capture this significant and topical evolution in which the boundaries between companies and customers are becoming more blurred due to the continuous redefinition of their roles" (Saarijärvi et al., 2013)

\section{Customer loyalty}

Customer loyalty is a complex construct because of the different perspectives in conceptualization (Majumdar, 2005). A general definition of belief is a commitment to repurchase a preferred product or service in such a way as to promote its repeat purchases. Loyal customers buy back from the same service supplier whenever possible, recommend these suppliers, and maintain a positive attitude (Kandampully \& Suhartanto, 2000). According to literature, there are two classes of loyalty (Baloglu, 2002; Kumar, Shah, \& Venkatesan, 2006): behavioral and attitudinal. From a behavioral perspective, belief is a way of behaving. Repeat purchases are an indicator of loyalty.

Under the attitude approach, commitment is a personal attitude in which different emotions shape consumer loyalty to a product, service, or retailer. Even if customers do not repeat purchases but recommend their suppliers' services to other customers, attitude loyalty is apparent (Kursunluoglu, 2011). This situation refers to the customer's preferences for the supplier, their intention to buy, and their recommendations to third parties. Attitudinal loyalty does not guarantee that a customer buys a product or service. However, word of mouth contributes to creating a positive business image.

Behavioral loyalty is a "substantial element," whereas attitude loyalty is a "psychological construct" (Cheng, 2011). Many studies have shown a positive relationship between attitude loyalty and behavioural loyalty (Baldinger \& 
Rubinson, 1996; Dick \& Basu, 1994). When customers experience a strong involvement in service delivery, they tend to spend part of their time searching for information (Beatty, Homer, \& Kahle, 1988). If the service satisfies the customer, the frequency of purchases in folds while reducing the search for alternatives occurs (Yang et al., 2014). Although different works show descriptions of loyalty through the mediating role of satisfaction (Lam, Shankar, Erramilli, \& Murthy, 2004), analysis of the possible direct influence between shared value creation and loyalty is a relevant consideration. Value co-creation can act as a kind of barrier to switching - apart from satisfaction - that directly affects customer loyalty.

\section{The Method, Data, and Analysis}

This article's design/methodology/approach is thought or conceptual based on intellectualization and reflects the prospects and impacts of digital marketing. This study uses a critical system to analytically review digital marketing literature and relate it to research results. Data analysis techniques used a descriptive

\section{Result and Discussion}

\section{Relationship Marketing and Islamic Personality}

The research finding (Iglesias et al., 2011) that the two shared vital values needed to implement relationship marketing successfully are client orientation and a high level of concern for employees. Also, J. N. Sheth \& Parvatiyar (2015) suggested six other shared values (trust, commitment, teamwork, innovation, flexibility, and results in orientation) also seem to facilitate a relationship marketing orientation. The study of religious personality is based solely on attitudes, practices, beliefs, world views, ethics and morals, altruism, and doctrinal orthodoxy. This study is also limited to afterlife motivation, coping methods, conversion, struggle, obligation, identification, exclusivism, and mysticism. Likewise, it is the conceptualization of personality on which the scale is based. Therefore, this study identifies and clarifies the integrative Islamic nature and develops deeper insights into personality traits and goals by working at both the theoretical and practical levels in an Islamic perspective, as suggested by Haque (2006).

In other words, Nik Ahmad Hisham \& Tekke, (2015) put forward the multi-dimensional concept of Islamic personality starting with personality theory, understanding Islamic monotheism, and ending with the idea of self or the manifestation of Western views in everyday life consistent with traditional Islam and authentic. Knowledge (i.e., the Qur'an and the Sunnah). Garbarino and Johnson (1999) examined the various roles of satisfaction, trust, and commitment in customer relationships and identified a range of customer relationships from transactional to relational. They find that relational customers want to trust and commitment from the companies they interact with, but transactional customers seek satisfaction from their interactions.

Proposition 1: Relationship marketing is positively and strongly correlated with Islamic personality

Relationship marketing and Value
Satisfaction


Relationship marketing theory implies that consumers enter into relational exchanges with firms when they believe that the benefits derived from these relational exchanges exceed costs. (Hunt et al., 2006) identified benefits including; the belief that individual partners can be trusted to reliably, competently, and non-opportunistically provide quality market offerings; the idea that partner companies share value with consumers; reduced customer experience in search costs; customers feel that the risks associated with market offerings are reduced; the exchange is consistent with moral obligations, and discussions allow for adjustments that result in better satisfaction of customer needs, wants, tastes, and preferences (Hunt et al., 2006).

Hunt et al. (2006) argue that companies engage in relationship marketing because it increases their competitiveness. Relational resources can improve a company's market position and, in turn, its financial performance. Statistical findings (Keshavarz \& Jamshidi, 2018) support the relationship between process quality and outcome quality with perceived value and tourist satisfaction, and tourist loyalty with perceived value and tourist satisfaction. The results also show that the quality of the process and the quality of the results do not directly affect tourist loyalty. Perceived value and tourist satisfaction mediate the relationship between process quality and outcome quality, and tourist loyalty.

Proposition 2: Good relationship marketing will increase consumer value satisfaction.

\section{Relationship Marketing and Customer Loyalty}

Several empirical studies have provided evidence on the impact of relationship marketing on behavioral loyalty that affects customer retention (Bolton, et al., 2000; Verhoef, 2003). Successful relationship marketing efforts increase customer loyalty and company performance through stronger relationship bonds (Sirdeshmukh, Singh, and Sabol, 2002). Relationship marketing is a strategic response by companies to gain a competitive advantage (Takala and Uusitalo, 1996). This response is based on the theory that an appreciation of market participants' interdependence and concerted efforts based on trust and commitment will enable firms to remain competitive (Veloutsou et al., 2002). In an environment that is continually evolving and changing rapidly, companies cannot maintain an attitude characterized by attracting customers or expanding new markets.

The critical success factors for survival in mature markets depend on long-term relationships with stakeholders (De Madariaga and Valor, 2007). Relationship marketing has proven successful in building trust and commitment with external stakeholders to create loyal customer relationships (Morgan \& Hunt, 1994). Using firms in China, Sin et al. (2005) developed and validated a scale consisting of six subscales - bonding, communication, shared value, empathy, reciprocity, and trust - and found that relationship marketing orientation had a significant impact on determining firm performance. "The benefits of relationship marketing are immense. many, including increased competitive advantage in markets (Day 2000; Hunt 1997), superior financial performance (Boles et al., 2000; Kalwani and Narayandas, 1995), and increased levels of customer satisfaction (Abdul-Muhmin, 2002). 
The structure of relationship marketing and its underlying dimensions vary across empirical studies, but at the heart of conceptualization is the belief that no single size or relational construct can fully determine the exchange relationship's depth or overall climate. Therefore, researchers have little agreement regarding individual or composite relational mediators that best capture the critical aspects of a relationship that most influence outcomes (Palmatier et al., 2006). Morgan and Hunt (1984) were the first to propose that building trust and commitment with customers and other stakeholders should be the rationale for relationship marketing.

Research (Alrubaiee \& Al-Nazer, 2010) reveals a significant effect of gender differences on relationship marketing and customer loyalty. That income has a significant impact on relationship marketing - customer loyalty. As far as the relative impact of the individual components of relationship marketing orientation on customer loyalty is concerned, the findings (Alrubaiee \& Al-Nazer, 2010) also reveal that bonding was the most dominant relational dimension in determining variations in customer loyalty. Surprisingly that commitment tends to have no impact on customer loyalty in Jordan's banking services. The effect on customer loyalty from four essential relationship marketing constructs according to (Husnain \& Akhtar, 2015) namely Trust, Commitment, Communication and conflict handling.

RM's strength shows that the five dimensions of RM - trust, empathy, shared value, communication, and bonds - have a significant positive effect on brand equity (Amoako, 2019). The results show that four variables have a considerable influence and predict the right proportion of customer loyalty variations. Based on this evidence, it is plausible to conclude that customer loyalty can be created, strengthened, and sustained by a marketing plan that aims to build trust, demonstrate a commitment to service, communicate with customers in a timely, reliable and proactive manner to handle conflicts efficiently. That the online banking relationship activity, over and above the online tools used, need to communicate appropriate and useful signals to positively influence online trust and loyalty among customers (Boateng, 2019).

Proposition 3: Good relationship marketing will increase customer loyalty.

\section{Islamic personality dan Value satisfaction}

Islam rewards personalities that involve virtue and good deeds, as according to the Quranic verse 87:14: "But they will prosper who purify themselves." Therefore, Abbas and Gibbs (1998) emphasize that Muslims should do good deeds in business and personal life because those who believe in and practice Islam is likely to be more committed to their organization and maybe more satisfied with their work (Yousef, 2001). When the five significant personalities are viewed from the perspective of individual Muslims, people are taught to be responsible and not commit sins (thorough), patient and tawakkal which means wholeheartedly (emotional stability), deliberation, which means consultation (conformity), refrain from speaking unproductively. (the opposite of extraversion) and shows humility and upholds the conservative values initially taught by the Quran and Prophet Muhammad (PBUH) (the opposite of openness to experience). Taking Islamic teachings and teachings based on their 
face value, one would expect to observe, for example, teamwork, consultative, participatory, egalitarian (equality) views among employees in Muslim organizations (Tayeb, 1997). These values, especially Conscience and Agreeableness, are wellpositioned to be an integral part of Islamic personality measures' proposed construction.

Tabasum et al. (2014) research results show that the quality of the seller's identity affects client perceptions and sales. Lily Wisker (2015) concluded that emotional stability was a positive indicator of sales performance in two samples. The impact of extraversion and agreeableness on sales performance was not large for the Muslim and non-Muslim samples. (Jos Akkermans, 2018) emphasizes the importance of trust and religiosity in consumer commitment to certain market offers and brands that always strengthen relationship marketing. The model entitled Brand, Faith Relationship model (BFR) is proposed to understand brand positioning in the market concerning the faith. With this model, four typological categories of brand positioning scenarios are suggested in this paper. (1) Passive Brand, Faith relationship, (2) Faith Trust is built in the absence of a brand, (3) Brand Loyalty without Faith association, and (4) Brand Loyalty, with Positive Brand, Faith relationship. Also, Luu et al., (2018) found that structural programs are more effective at creating value in long-term relationships than in short-term relationships; therefore, as purchasing firms age, managers should consider investing more in structural programs to develop their relationships.

Proposition 4: With an excellent Islamic personality will be able to increase consumer value satisfaction

\section{Islamic personality and Customer loyalty}

Here we use sales performance as a proxy for customer loyalty because, in essence, loyal consumers will continue to use the company's products and will increase the company's sales performance. Research by Fauzilah and Abdul Razak (2011) shows that the higher the sales representatives' self-efficiency and selfmonitoring, the higher the targets they can achieve, while the locus of control shows a negative correlation with the sales representative's performance. The results of Reynaldi Abryan Zainal Abidin's research (2016) show that representatives who have selfobserver identity have great and effective execution in meeting daily targets; The employee or identity extrovert specialist also performs great and is beneficial in meeting day-to-day goals. Punwatkar, S., \& Varghese, M. (2014) from their research show that product knowledge, convincing skills, objection handling and interpersonal skills are significant skills that affect sales representatives' presentations and advise directors to look for staff who focus on learning and consider ranges take longer to monitor and rate them to improve the longterm presentation of the sales persona.

Magandini and Tendai Ngwenya (2015) show that the performance of $35 \%$ of respondents affects the achievement of sales targets so that self-efficiency has a positive impact. Other respondents indicated that a person with a positive attitude who has control in any situation has an $86 \%$ chance of closing a transaction, so that locus of control also affects sales performance. $77 \%$ of respondents agree that a proactive personality is essential in maintaining relationships. Echchakoui's (2013) findings indicate that Conscientiousness, Agreeableness, Extraversion, Emotional Stability and Openness to Experience all have a positive 
effect on sales performance with clients. Also, adaptive behaviour significantly affects worker performance with clients while only three characteristics (awareness, orderliness, and emotional stability) positively influence sales of the person's adaptive behaviour. The findings of Yeboah, et al. (2014) show that there is a significant factual relationship between organizational culture, sales performance and personality traits. (Saeed \& Siddiqui, 2020) concludes their research that righteousness, forgiveness and truth affect sales performance positively because these factors play an important role in sales performance.

Proposition 5: With an excellent Islamic personality will be able to increase customer loyalty

\section{Value satisfaction and Customer loyalty}

Consumer value is the foundation of a successful transaction, and it motivates consumers to buy repeatedly (Holbrook, 1994). The expectation disconfirmation paradigm shows that after consumers have had a satisfying experience with a product, they have better value expectations and tend to buy back the same product in the future rather than a switch (Anderson \& Srinivasan, 2003). Yang and Petersson (2004) show that value is a super-ordinate goal and positively regulates loyalty behaviour, which is at the subordinate level.

The results of the study Yeh et al., (2016) show that functional values, emotional values, social values, and brand identification have a positive influence on smartphone brand loyalty. Of the two moderators, the results show that age increases the emotional valuebrand loyalty and the social value-brand loyalty relationship but weakens the brand identification-brand loyalty relationship. However, gender does not play a moderate role in determining smartphone brand loyalty. Previous studies have found evidence of an association between functional benefits and brand loyalty, and they report that brands that offer high functional value generate consumer preference and loyalty. Research (Cossío-Silva et al., 2016) proves that there is evidence to corroborate the relationship between shared value creation and attitude loyalty. Value cocreation explains $34.2 \%$ of the variance of attitude fidelity and has high statistical significance. The literature analyzes more factors regarding antecedents of loyalty, such as satisfaction (Dick \& Basu, 1994), trust (Amin, Zaidi, \& Fontaine, 2013), and perceived value. (Pizzutti \& Von der Heyde, 2008; Sirdeshmukh, Singh, \& Sabol, 2002).

Attitudinal loyalty conditions repeat buying behaviour; This attitude explains $18.32 \%$ of behavioural loyalty. This relationship confirms that past behavioural intentions largely determine effective behaviour (Ajzen, 1985). Other results (Cossío-Silva et al., 2016) do not confirm that value creation has a direct effect on loyalty behaviour towards firms. Various intermediaries or mediators may exist in this relationship, such as factors of personal character, level of one's experience with service, and level of satisfaction. All of these factors can influence this relationship.

High customer value leads to high customer retention rates (Naumann, 1995). Customer satisfaction and customer loyalty can be empirically recognized as a result of perceived value (Brodie et al., 2009; Gallarza and Gil, 2006; Hutchinson et al., 2009). Chong (2017) found that Malaysian customers are loyal to hotels because they find that the hotel loyalty 
program is beneficial and will provide benefits for them. Overall, the surveys cited above have highlighted perceived value as a determinant of loyalty (Gill et al., 2007; Kim et al., 2008; Poon and Low, 2005; Nasution and Mavondo, 2008; Oh, 1999). Cronin et al. (2000) found that perceived value has a significant direct effect on behavioural intentions that are perceived as the concept of attitude loyalty. There is a paradigm known as disconfirmation-of-expectation, which states that satisfaction contributes to loyalty (Oliver, 1980). In detail, being satisfied by utilizing a product or service grows and engenders customer confidence in the quality of the product or service. This ends in a tendency to be repurchased. As evidenced by the results reported by various studies across various industries, there is an established correlation between customer satisfaction and loyalty (Lai et al., 2009; Ali et al., 2016).

There is a positive relationship between guest satisfaction and loyalty (Chitty et al., 2007; Kim et al., 2008; Yoon and Uysal, 2005). However, most of these studies only explore the correlation between customer satisfaction and conative (Chitty et al., 2007, cognitive (Return, 2005), or overall loyalty (Han et al., 2008). However, Heskett et al. (1997) stated that the relationship between customer satisfaction and customer loyalty was the weakest relationship. In fact, it was concluded that less than 40 per cent of guests who rated a particular service more satisfactory to return, while 90 per cent of those who ranked the high level of satisfaction intended to produce.

Proposition 6: High-value satisfaction will increase customer loyalty.

Figure 1. The Framework

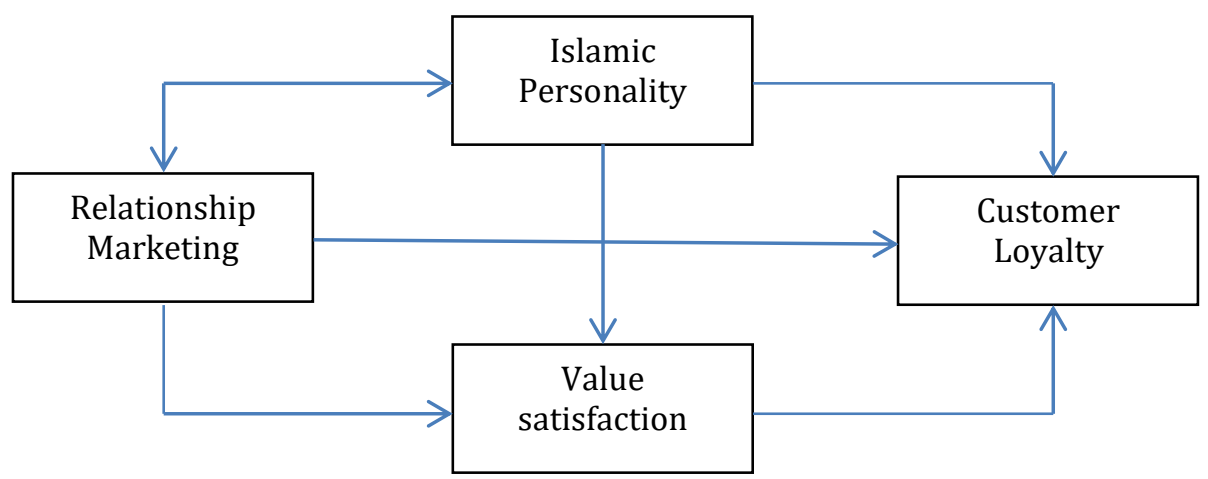

Table 3. Indicator Variabel

\begin{tabular}{|c|c|c|c|}
\hline No & Variable & Indicator & Source \\
\hline 1 & $\begin{array}{l}\text { Relationship } \\
\text { marketing }\end{array}$ & $\begin{array}{ll}- & \text { Build trust } \\
\text { - } & \text { Commitment } \\
\text { - } & \text { Team work } \\
\text { - } & \text { Innovation }\end{array}$ & $\begin{array}{l}\text { Iglesias et al., (2011); } \\
\text { J. N. Sheth \& Parvatiyar, } \\
(2015)\end{array}$ \\
\hline
\end{tabular}




\begin{tabular}{|c|c|c|c|}
\hline & & $\begin{array}{ll}\text { - } & \text { Flexibility } \\
\text { - } & \text { Result orientation }\end{array}$ & \\
\hline 2 & Islamic personality & $\begin{array}{ll} & \text { Tauhid } \\
\text { - } & \text { Nubuwwa } \\
\text { - } & \text { self-striving } \\
\text { - } & \text { Self-respect }\end{array}$ & $\begin{array}{l}\text { Nik Ahmad Hisham \& } \\
\text { Tekke, (2015) }\end{array}$ \\
\hline 3 & Value satisfaction & $\begin{array}{ll}\text { - } & \text { Functional value satisfaction } \\
\text { - } & \text { Emotional value satisfaction } \\
\text { - } & \text { Social value satisfaction } \\
\text { - } & \text { Brand identification }\end{array}$ & Yeh et al., (2016) \\
\hline 4 & Consumer loyalty & $\begin{array}{ll} & \text { Behavioural } \\
\text { - } & \text { Attitudinal } \\
\text { - } & \text { Repeat purchase } \\
\text { - } & \text { Recommend }\end{array}$ & $\begin{array}{l}\text { Baloglu (2002); Kumar, } \\
\text { Shah, \& Venkatesan } \\
(2006)\end{array}$ \\
\hline
\end{tabular}

\section{Conclusion}

The role of marketing is to facilitate decisions seeking rational utility in competitive markets. This study trying to develop a better understanding of what drives consumer loyalty towards a product has become an important issue for both academics and practice. Based on the literature review, it produces propositions that determine consumer loyalty in a product that is influenced by the effectiveness of relationship marketing. This study also discusses the mediating effect of Islamic personality and consumer perceived value satisfaction. This concept is the first to link value satisfaction and customer value loyalty. Based on the results of reference tracing, there are still few researchers who test the reciprocal relationship between relationship marketing and Islamic personality. Islamic personality is positioned as an antecedent variable and a mediating variable. In addition, in this study, we propose the merging of perceived value and consumer satisfaction into value satisfaction, as well as examining the relationship with other variables. After reviewing the literature, finally, there are six propositions that are proposed to be followed up into empirical research.

\section{Recommendation}

The characterization of digital marketing from an Islamic perspective will open new avenues for future research and will make researchers more theoretically sensitive to the ontological and epistemological assumptions underlying Islamic marketing research. But the limitations of the study of digital marketing in an Islamic context are very rare. Practical implications, practitioners must realize that technological advances have given birth to a transaction method known as digital marketing so that it is an opportunity for business people to evaluate data and use digital marketing to improve their marketing. In theory, practitioners and academics will find a better platform for developing digital marketing from an Islamic perspective. 


\section{References}

Alrubaiee, L., \& Al-Nazer, N. (2010). Investigate the Impact of Relationship Marketing Orientation on Customer Loyalty: The Customer's Perspective. International Journal of Marketing Studies, 2(1), 155-174. https://doi.org/10.5539/ijms.v2n1p155

Amoako, G. K. (2019). Relationship Marketing, Orientation, Brand Equity and Firm Value: The Mediating Role of Customer Value-An Emerging Market Perspective. Journal of Relationship Marketing, 18(4), 280-308. https://doi.org/10.1080/15332667.201 9.1639589

Boateng, S. L. (2019). Online relationship marketing and customer loyalty: a signaling theory perspective. International Journal of Bank Marketing, 37(1), 226240. https://doi.org/10.1108/IJBM-012018-0009

Cossío-Silva, F. J., Revilla-Camacho, M. Á., Vega-Vázquez, M., \& Palacios-Florencio, B. (2016). Value co-creation and customer loyalty. Journal of Business Research, 69(5), 1621-1625. https://doi.org/10.1016/j.jbusres.2015. 10.028

Hunt, S. D., Arnett, D. B., \& Madhavaram, S. (2006). The explanatory foundations of relationship marketing theory. Journal of Business and Industrial Marketing, 21(2), 72-87.

https://doi.org/10.1108/106104206106 51296

Husnain, M., \& Akhtar, W. (2015). Relationship Marketing and Customer
Loyalty: Evidence from Banking Sector in Pakistan. Type: Double Blind Peer Reviewed International Research Journal Publisher: Global Journals Inc, 15(10).

Iglesias, O., Sauquet, A., \& Montaña, J. (2011). The role of corporate culture in relationship marketing. European Journal of Marketing, 45(4), 631-650. https://doi.org/10.1108/030905611111 11361

Jos Akkermans, A. H. de L. (2018). 기사 (Article) 와안내문 (Information) [. The Eletronic Library, 34(1), 1-5.

Keshavarz, Y., \& Jamshidi, D. (2018). Service quality evaluation and the mediating role of perceived value and customer satisfaction in customer loyalty. International Journal of Tourism Cities, 4(2), 220-244.

https://doi.org/10.1108/IJTC-09-20170044

Khir, M. M., Othman, A. K., Hamzah, M. I., Demong, N. A. R., Omar, E. N., \& Abbas, M. K. M. (2016). Islamic Personality Model: A Conceptual Framework. Procedia Economics and Finance, 37(June), 137-144. https://doi.org/10.1016/s22125671(16)30104-6

Luu, N., Ngo, L. V., \& Cadeaux, J. (2018). Value synergy and value asymmetry in relationship marketing programs. Industrial Marketing Management, 68, $165-176$ https://doi.org/10.1016/j.indmarman.2 017.10.011

Nadhifah, H. H., \& Adinugraha, H. H. (2020). Analysis of Factors influencing 
the Purchasing Decision of Facial Foam labeled Halal. Journal of Digital Marketing and Halal Industry, 2(1), 65-80.

Nik Ahmad Hisham, I., \& Tekke, M. (2015). Development and initial validation of integrative islamic personality inventory. Advances in Environmental Biology, 9(18), 163-170.

O'Malley, L. (2014). Relational marketing: development, debates and directions. Journal of Marketing Management, 30(11. 12), 1220-1238. https://doi.org/10.1080/0267257X.201 4.939592

Othman, A. K., Hamzah, M. I., \& Hashim, N. (2014). Conceptualizing the Islamic Personality Model. Procedia - Social and Behavioral Sciences, 130, 114-119. https://doi.org/10.1016/j.sbspro.2014.0 4.014

Othman, N. (2015). A Preface to the Islamic Personality Psychology. International Journal of Psychological Studies, 8(1), 20. https://doi.org/10.5539/ijps.v8n1p20

Saeed, S., \& Siddiqui, D. A. (2020). The Impact of Muslim Personality Traits on Sales Performance in Islamic Banks. February 2018.

Sheth, J. N., \& Parvatiyar, A. (2015). The Evolution of Relationship Marketing Orientations. 5931(4), 25-37. https://doi.org/10.4018/978-1-4666-

\section{1-3.ch002}

Sheth, J., Parvatiyar, A., \& Berry, L. L. (2014). Relationship Marketing of Services: Growing Interest, Emerging Perspectives. Handbook of Relationship Marketing, 23(4), 149-170. https://doi.org/10.4135/978145223131 $0 . n 6$

Styles, C., \& Ambler, T. (2003). The coexistence of transaction and relational marketing: Insights from the Chinese business context. Industrial Marketing Management, 32(8), 633-642. https://doi.org/10.1016/j.indmarman.2 003.06 .004

Thommen, J.-P., Achleitner, A.-K., Gilbert, D. U., Hachmeister, D., Jarchow, S., Kaiser, G., Thommen, J.-P., Achleitner, A.-K., Gilbert, D. U., Hachmeister, D., Jarchow, S., \& Kaiser, G. (2020). Marketingmix. Allgemeine Betriebswirtschaftslehre, 145-148. https://doi.org/10.1007/978-3-65827246-3_10

Yeh, C. H., Wang, Y. S., \& Yieh, K. (2016). Predicting smartphone brand loyalty: Consumer value and consumer-brand identification perspectives. International Journal of Information Management, 36(3), 245-257. https://doi.org/10.1016/j.ijinfomgt.201 5.11 .013 